\title{
The occurrence of Salpingoporella milovanovici Radoičić (Dasycladales) in the Cenomanian of south Apennines and Dinarides
}

\author{
Andrea Sgrosso \& Paola Esposito \\ Dipartimento Scienze della Terra, Università "Federico II" \\ 30138 - Napoli, Largo Marcellino, 10, Italy \\ Rajka Radoičić \\ Kr. Petra, 38, 11000 Beograd, Yugoslavia
}

Key words: Dasycladales, Cenomanian, Periadriatic Carbonate Platforms, Apennines, Dinarides

\begin{abstract}
The findings of dasycladacea Salpingoporella milovanovici in Cenomanian of Dinaridic and Campania-Lucania Carbonate Platforms suggest that this little known species has had significant geographic distribution within Periadriatic Carbonate Platforms (Adriatic, Dinaric, Campania-Lucania; type region: Mirdita Zone, Internides).
\end{abstract}

Dasycladacea Salpingoporella milovanovici is described from the Cenomanian limestone of Paštrik mountain (Mirdita Zone) (R a d o i č i ć, 1978). In addition to several localities on the type region, the species was also found in Cenomanian rocks of Vodice in Dalmatia (Adriatic Carbonate Platform). Limestones with Salpingoporella milovanovici on Mt Paštrik bear an assemblage of foraminifers with Pseudorhipidionina casertana (De Castro), Pseudorhapydionina laurinensis (De Castro). Broeckinella (Pastrikella) balcanica Cherchi, Radoičić \& Schroeder, Nezzazata gyra (Smout), Trochospira avnimelechi Hamaoui \& Saint-Marc, Murgeina apula (Luperto-Sinni) and Nezzazatinella spp.

The Apennines: Campania-Lucania Carbonate Platform

The outcropping terrains in Monti di Lauria assigned to Campania-Lucania Carbonate Platform. The sedimentary rocks sequence in this region consists primarily of Lower and Upper Cretaceous limestones and dolomites and less extensive Tertiary deposits. Salpingoporella milovanovici was found in Cenomanian limestone in two localities of Lauria area: Monte Messina and Serra Vaddellona. 
A Lower Cenomanian dolomite sequence by the road on Monte Messina eastern slopes includes only one bed of foraminiferal limestone (wackeston - grainstone). In this limestone foraminiferal association with frequent Nummoloculina heimi Bonet and other miliolids, rare Biconava bentori Hamaoui \& Saint-Marc, Trochospira cf. avnimelechi Hamaoui \& Saint-Marc, Nezzazatinella spp., Broeckinella sp. and Cuneolina sp. have been observed. The few dasyclads are represent with Salpingoporella milovanovici and Cylindroporella cf. C. parva Radoičić.

The dolomite sequence at Serra Vaddellona western slopes includes several beds of limestone with radiolitids. Salpingoporella milovanovici was recognized in one of the beds with scarce foraminiferal association - Pseudorhapydionina dubia (De Castro), Pseudorhapydionina cf. P. laurinensis, Biconcava bentori, Pyrgo globulosa Tronchetti and other miliolids.

\section{The Dinarides: Dinaric Carbonate Platform}

Cenomanian deposits near Nikšić (Montenegro) consist of sporadic occurrences of limestones with radiolitids and the prevailingly scarce microfossil content, in addition to beds bearing Chondrodonta joannae Choffat and/or other oysters. Scarce foraminiferal assemblage is formed by Pseudorhapydionina dubia, Pseudorhapydionina laurinensis, Cuneolina, Dicyclina, Nezzazatinella and different miliolids. Algae, Heteroporella lepina Praturlon, Neomeris sp. and Salpingoporella milovanovici are fewer. Localities: west of the Krupac dam and north of Gornje Polje.

Salpingoporella milovanovici has been recognized in similar Cenomanian limestones of Popovo Polje area (Hercegovina).

\section{Observation on Salpingoporella milovanovici}

Few specimens of slightly larger thallus than those in the type region are noted in limestones of Serra Vaddellona and Nikšić area. According to all of the available data, the measurements od Salpingoporella milovanovici are the following:

Outer diameter of calcareous tubes

Diameter of canal

Distance between whorls

Number of branches in the whorl

$$
\begin{gathered}
0.070-0.320 \mathrm{~mm} \\
0.035-0.190 \mathrm{~mm} \\
0.040-0.080 \mathrm{~mm} \\
9-16
\end{gathered}
$$

Calcareous envelope around proximal part of the branches forms a compact tube. Distally, between two successive verticils, the envelope tapers into thin laminae which reach the subcortical part of the thallus and are mainly either partly preserved or barely discernible. The envelope is sometimes reduced to a narrow part around the axis - the sections of such tube resemble those of Salpingoporella annulata similarly preserved.

The contour of axial cavity has not always been visible, particularly when these fossils (as in Serra Vaddellona limestones) present calcite moulds of the original envelope. The minute poorly preserved Salpingoporella milovanovici are often difficult to recognize as dasycladacean and are easily overlooked. The likely reason is the absence of registered findings since the introduction of the species. 
The findings reported in this note suggest a significant geographic distribution of Cenomanian Salpingoporella milovanovici, especially within the Periadriatic Carbonate Platforms. The favourable habitat of Salpingoporella milovanovici were protected platform areas.

\section{References}

R a d o i č i ć, R. 1978: Salpingoporella milovanovici, n. sp. a new dasyclad from the Cenomanian strata of Dinarides, and a note on the foraminifer Nummoloculina sp. (aff. regularis, Philippson). - Ann. Géol. de Pénin. Balkanique, Tome XLII, 375-381, Beograd. 

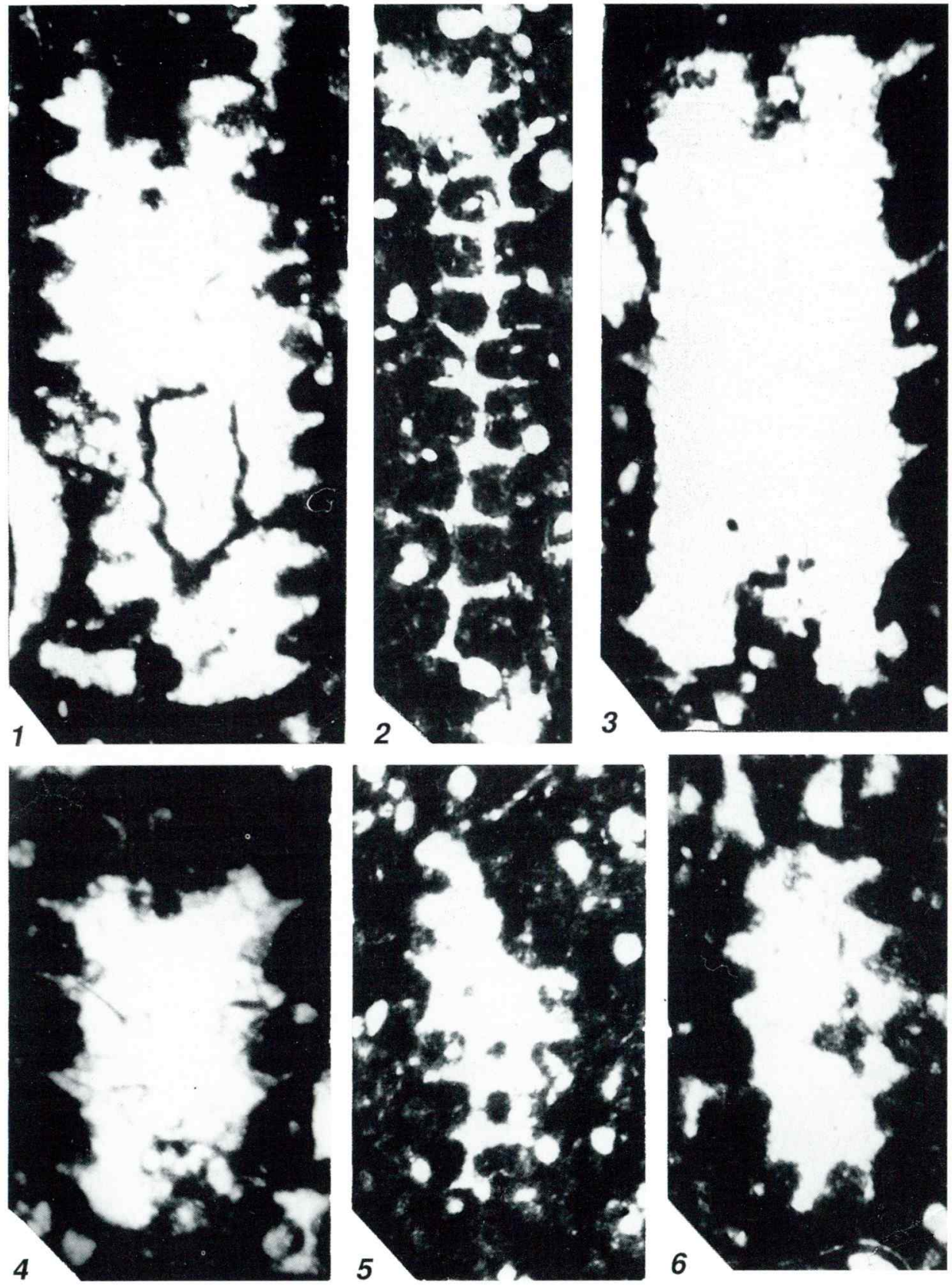

Plate 1

1-6 Salpingoporella milovanovici Radoičić, $\times 130$, vertical, tangential and oblique sections, Lower-Middle Cenomanian, sample AS81, Serra Vaddellona 

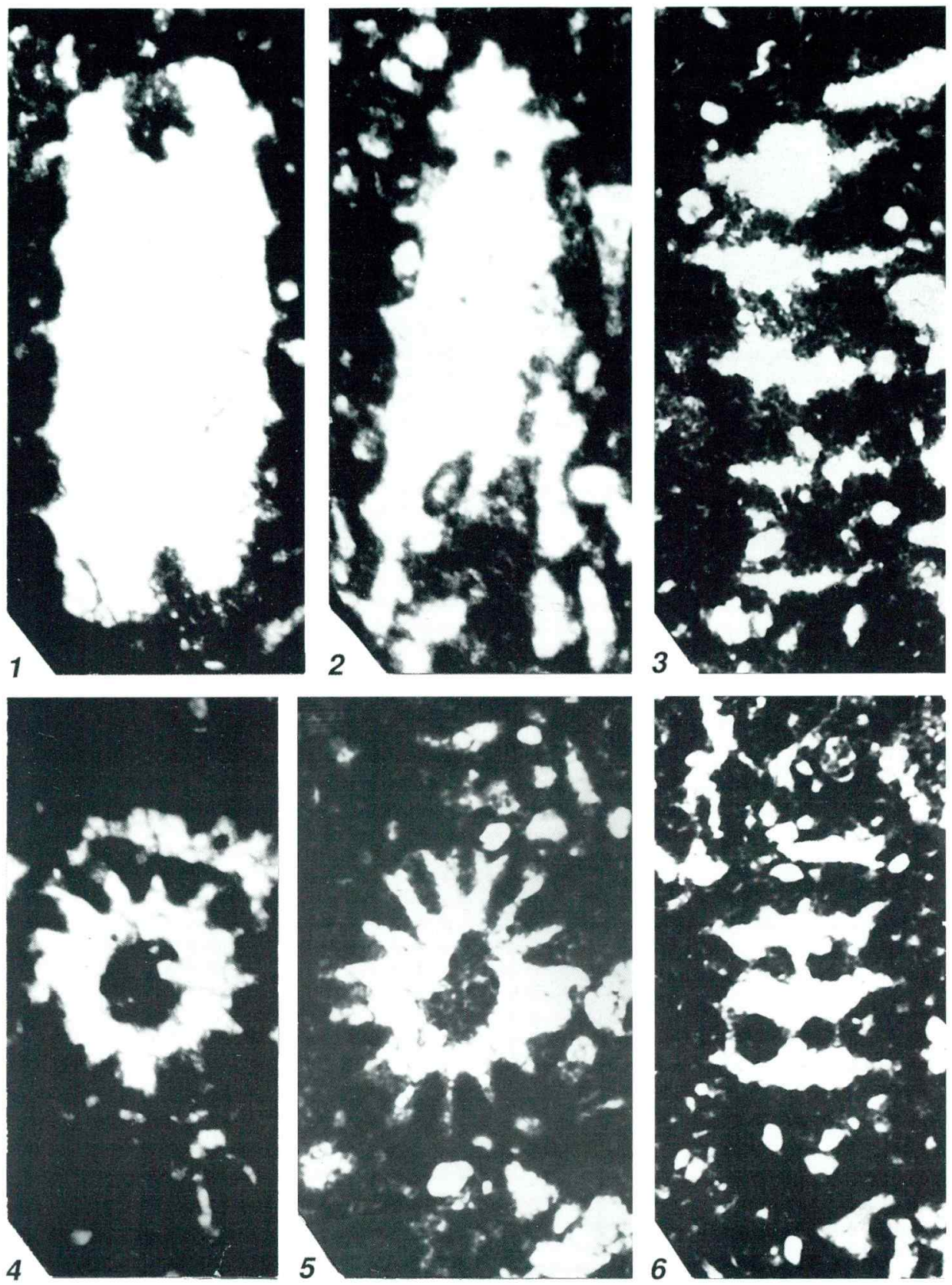

Plate 2

1-6 Salpingoporella milovanovici Radoičić, $\times 130$, vertical, oblique, tangential (figs. 1-3, 6) and transverse sections (figs. 4, 5), Lower-Middle Cenomanian, sample AS81, Serra Vaddellona 